\title{
A case of cervical esophageal duplication cyst in a newborn infant
}

\author{
Shoko Kawashima ${ }^{1,2}$, Osamu Segawa ${ }^{1,2^{*}}$, Shuri Kimura ${ }^{2}$, Masayoshi Tsuchiya ${ }^{1,2}$, Nobuhide Henmi $^{3}$, \\ Hisaya Hasegawa ${ }^{3}$, Mariko Fujibayashi ${ }^{4}$ and Yoshihiko Naritaka ${ }^{1}$
}

\begin{abstract}
Esophageal duplication cyst is a rare congenital anomaly resulting from a foregut budding error during the fourth to sixth week of embryonic development. Cervical esophageal duplication cysts are very rare and may cause respiratory distress in infancy. A full-term newborn girl who was born by normal delivery was transferred to our hospital because of swelling of the right anterior neck since birth. Cervical ultrasonography showed a $40 \times 24 \times$ $33 \mathrm{~mm}$ simple cyst on the right neck. Tracheal intubation was required at 2 weeks of age because of worsening external compression of the trachea. Fine-needle aspiration cytology revealed the existence of ciliated epithelium. At 1 month of age, exploration was performed through a transverse neck incision. The cyst had a layer of muscle connected to the lateral wall of the esophagus. Histopathological diagnosis was a cervical esophageal duplication cyst. We describe the clinical features of infantile cervical esophageal duplication cysts based on our experience of this rare disease in a neonate, along with a review of 19 cases previously reported in literature.
\end{abstract}

Keywords: Congenital duplication cyst, Esophagus, Cervical, Newborn, Simple cyst

\section{Background}

Esophageal duplication cysts are rare congenital cystic masses resulting from an error in foregut budding in the developing embryo and with a reported incidence of 1 in 8200 autopsies [1]. Most esophageal duplication cysts are in the thorax; involvement of the cervical region is distinctly rare. We report the case of a neonate with cervical esophageal duplication cyst at birth and describe the features of infantile cervical esophageal duplication cysts along with 19 infantile case reports.

\section{Case presentation}

A full-term newborn girl was transferred and admitted to our hospital because of swelling of the right anterior neck since birth (Fig. 1a). She did not manifest with respiratory distress and feeding difficulty on admission.

Cervical ultrasonography (Fig. 1b) showed a simple cyst measuring $40 \times 24 \times 33 \mathrm{~mm}$ on the right neck. Magnetic resonance imaging (MRI) showed a simple cyst

\footnotetext{
* Correspondence: osamu@surg2.twmu.ac.jp

1 Department of Surgery, Tokyo Women's Medical University Medical Center

East, 2-1-10 Nishi Ogu, Arakawa-ku, Tokyo 116-8567, Japan

${ }^{2}$ Department of Pediatric Surgery, Tokyo Women's Medical University, 8-1

Kawada-cho, Shinjuku-ku, Tokyo, Japan

Full list of author information is available at the end of the article
}

that displaced the sternocleidomastoid muscle anteriorly, the carotid sheath to the right, and the larynx and trachea to the left (Fig. 1c). The distal edge of the cyst was attached to the thymus.

Bronchoscopy (Fig. 1d) demonstrated extrinsic compression of the trachea from the subglottis to the carina, which eventually worsened and necessitated airway control with nasotracheal intubation at 2 weeks of age. Fine-needle aspiration cytology of the cyst revealed the existence of ciliated epithelium, suggesting a bronchogenic cyst.

Barium esophagography did not show stenosis, deformity, or tracheoesophageal fistula.

Exploration was performed through a transverse neck incision at 1 month of age (Fig. 2). Adhesiolysis of the cyst from the right carotid artery and vein, thymus, vertebrae, and trachea was performed without perforation. The cyst had a layer of muscle and was connected to the esophageal muscle layer. Therefore, we considered that it was an esophageal duplication cyst. Incision of the muscle layer was made slightly lateral to the border of the cyst and esophagus to avoid injury of the esophageal mucosa. The muscle layer of the esophagus was repaired. There was no communication between the cyst and the esophageal lumen. We had imaged the vagus 


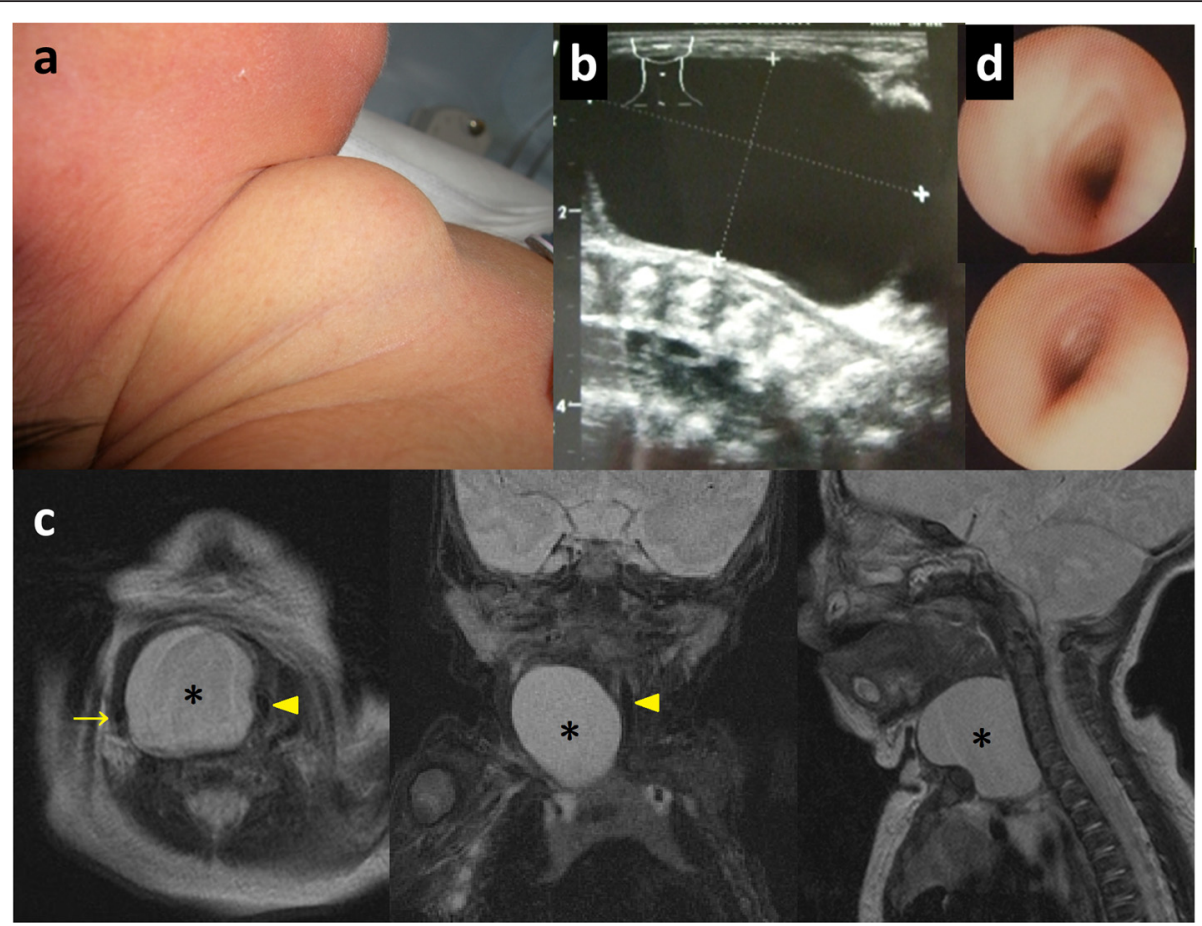

Fig. 1 Clinical findings in a newborn infant girl with esophageal duplication cyst. a On physical examination, there was anterior neck swelling on the right. b Ultrasonography showed a simple cyst measuring $40 \times 24 \times 33 \mathrm{~mm}$ in the right neck. c T2-weighted enhanced magnetic resonance imaging revealed a simple cyst (asterisk) that displaced the sternocleidomastoid muscle anteriorly, the carotid sheath (arrow) to the right, and the larynx and trachea (arrow head) to the left. $\mathbf{d}$ Bronchoscopy showed compressive deformation of the trachea from the subglottis to the carina

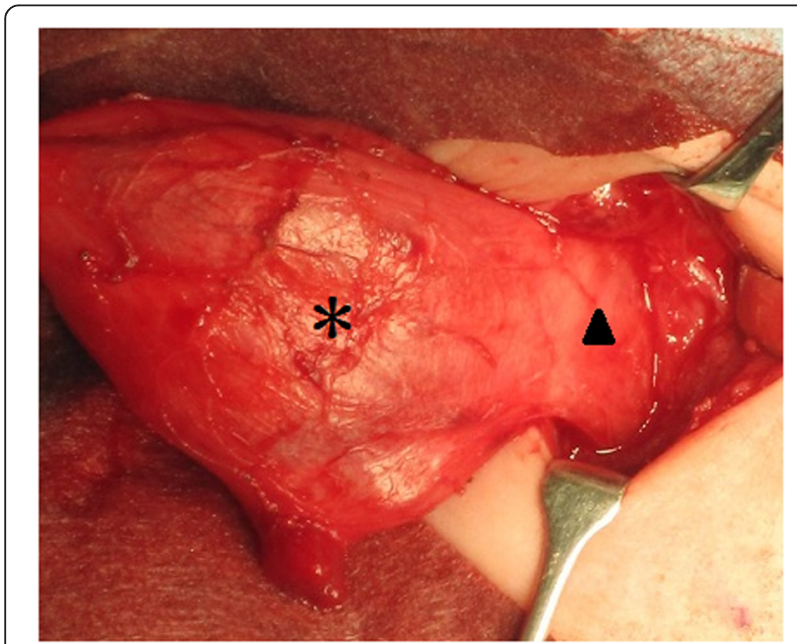

Fig. 2 Intraoperative findings in an infant girl who underwent surgical exploration of an esophageal duplication cyst at 1 month of age. The cyst was separated from the right carotid artery and vein, thymus, vertebrae, and trachea. The cyst (asterisk) had a layer of muscle and was connected with the lateral wall of the esophagus (arrow head) nerve was around the cyst; however, the vagus nerve was not detected during operation as a result of deviating from normal position.

Pathologic examination of the cyst showed an internal layer with pseudostratified ciliated epithelium (Fig. 3a) with covering layers of smooth muscle and striated muscle (Fig. 3b). The whole cyst was covered by smooth muscle layer, and about two-thirds of the cyst was covered by striated muscle layer. The luck of the striated muscle layer was the bottom of the cyst, contiguous with the thymus and innominate artery. Bronchial gland and cartilage were not present. A final diagnosis of cervical esophageal duplication cyst was made.

Extubation was carried out the day after the operation. Repeat bronchoscopy showed disappearance of the compressive deformation of the trachea. Transient right recurrent laryngeal nerve palsy was observed and controlled by nasal direct positive airway pressure for 3 weeks.

Postoperative barium esophagography showed good peristalsis without any extravasation or stricture. The patient has been doing well for 4 years now.

\section{Discussion}

Esophageal duplication cysts are rare congenital cystic masses resulting from a foregut budding error during the fourth to sixth week of embryonic development [2]. 


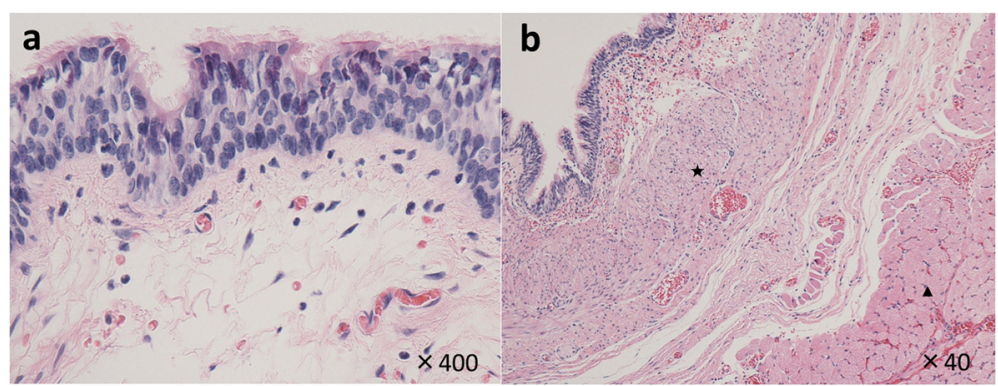

Fig. 3 Photomicrographs of a surgically resected infantile esophageal duplication cyst. a Pathologic examination showed an internal layer with pseudostratified ciliated epithelium (hematoxylin and eosin stain $\times 400$ ) with $\mathbf{b}$ covering layers of smooth muscle (star) and striated muscle (arrow head) (hematoxylin and eosin stain $\times 40$ )

The primitive foregut divides into dorsal and ventral segments; the dorsal segment ultimately differentiates into the esophagus, whereas the ventral segment develops into the tracheobronchial tree $[3,4]$.

Foregut budding error may lead to bronchogenic cyst, esophageal duplication cyst, or "bronchopulmonary foregut malformations" (BPFM), a term proposed in 1968 by Gerle et al. [5] to encompass the full spectrum of developmental aberrations of the embryonic foregut. The presence of an accessory lung bud distal to the normal lung bud has been proposed as the underlying basis of BPFM [6]. An interesting theory is that all BPFMs belong to a homogeneous group with a common embryologic pathogenesis. This group includes pulmonary sequestration, tracheoesophageal fistula, intestinal duplication cysts, neurenteric cysts, systemic arterializations of the lung, bronchogenic cysts, esophageal diverticula, and ectopic bronchial mucosal rests in the esophageal wall [7].

Esophageal duplication cyst is one of the gastrointestinal duplications that are rare congenital malformations occurring anywhere from the mouth to the anus. About 10 to $15 \%$ of all duplication cysts in the gastrointestinal tract are esophageal [7]. In a review of 49,196 autopsies, the incidence of esophageal duplication cyst was 1:8200 [1]. The location of the cysts in the esophagus was in the lower third in $60 \%$, in the middle third in $17 \%$, and in the upper third in $23 \%[1,8]$.

Even among cervical cysts, esophageal duplication cysts are quite rare. As for the differential diagnosis, Hsieh et al. reported on 331 pediatric patients diagnosed as having cervical cysts [9]. From the results of histology, thyroglossal duct cysts accounted for $54.68 \%$ of all cases, followed by cystic hygromas (25.08\%), branchial cleft cysts $(16.31 \%)$, bronchogenic cysts $(0.91 \%)$, and thymic cysts $(0.30 \%)$. Nine cases $(2.72 \%)$ remained unclassified. There was no cervical esophageal duplication cyst among the 331 infants.

In 1937, Ladd suggested the use of the term "duplications of the alimentary tract" and applied the term to congenital lesions having three characteristics: (1) the presence of a well-developed coat of smooth muscle, (2) an epithelial lining representing some type of intestinal tract mucosa, and (3) intimate anatomic association with some portion of the gastrointestinal tract [10].

The histopathological criteria for classifying a foregut duplication cyst as an esophageal cyst were developed by Arbona et al. [1] as follows:

1. The cyst is within or attached to the esophageal wall.

2. It is covered by two muscle layers.

3. The lining is squamous, columnar, cuboidal, pseudostratified, or ciliated epithelium.

In contrast to esophageal cysts, bronchogenic cysts are diagnosed based on the presence of cartilage $[2,3,11]$. Differentiating one from the other and making a definitive diagnosis before operation are difficult.

The definitive treatment for cervical esophageal duplication cysts is surgical removal, and it has been reported that there is no recurrence after exploration. Total exploration is important for suspected esophageal duplication cyst because of a possibility of coexistent squamous cell carcinoma [1, 12].

Twenty case reports of infantile cervical esophageal duplication cysts, including our own, were found upon review of English literature (Table 1) [13-29]. Our case was the sixth among newborns. Of note, 12 patients presented with signs of respiratory distress, such as stridor, in infancy; two presented with feeding difficulty; five presented with fever and/or respiratory infection; and three had asymptomatic neck swelling on admission. One case had concomitant tracheoesophageal fistula [18]. Ultrasonography, computed tomography, and MRI revealed tracheal deviation in 19 cases. Respiratory distress was caused by tracheal compressive deformation and deviation in 12 cases (60\%), three of which needed tracheal intubation. Respiratory symptoms were the most common symptoms of cervical esophageal duplication cysts in children. Consequently, these cysts should be 
Table 1 A literature review of infantile cases of cervical esophageal duplication cyst

\begin{tabular}{|c|c|c|c|c|c|c|c|c|c|c|c|c|c|}
\hline Number & Age & Sex & $\begin{array}{l}\text { Respiratory } \\
\text { distress }\end{array}$ & $\begin{array}{l}\text { Poor } \\
\text { feeding }\end{array}$ & $\begin{array}{l}\text { Fever and/or } \\
\text { respiratory } \\
\text { infection }\end{array}$ & $\begin{array}{l}\text { Palpable } \\
\text { mass }\end{array}$ & $\begin{array}{l}\text { Tracheal } \\
\text { deviation }\end{array}$ & Others & $\begin{array}{l}\text { Antenatal US } \\
\text { detection }\end{array}$ & $\begin{array}{l}\text { Communication } \\
\text { with esophagus }\end{array}$ & Size (cm) & $\begin{array}{l}\text { Surgical } \\
\text { intervention }\end{array}$ & Author (year) \\
\hline \multirow[t]{2}{*}{1} & \multirow[t]{2}{*}{25 days } & \multirow[t]{2}{*}{ M } & \multirow[t]{2}{*}{+} & & & \multirow[t]{2}{*}{+} & \multirow[t]{2}{*}{+} & & & & & Tracheostomy & \multirow{2}{*}{$\begin{array}{l}\text { Bishop and Koop } \\
\text { (1964) [13] }\end{array}$} \\
\hline & & & & & & & & & & & & $\begin{array}{l}\text { Resection at a } \\
\text { later time }\end{array}$ & \\
\hline 2 & 6 years & \multirow[t]{2}{*}{ M } & - & - & - & \multirow[t]{2}{*}{+} & + & & & - & 5 & A collar incision & Gans (1968) [14] \\
\hline 3 & 2 months & & + & - & + & & + & & & - & $4 \times 5 \times 3$ & $\begin{array}{l}\text { Transverse neck } \\
\text { incision }\end{array}$ & Gans (1968) [14] \\
\hline 4 & 3.5 months & M & + & & & + & + & & & - & & $\begin{array}{l}\text { Transverse neck } \\
\text { incision }\end{array}$ & Winslow (1984) [15] \\
\hline 5 & 9 days & M & + & & & & + & $\begin{array}{l}\text { Resuscitation, } \\
\text { intubation }\end{array}$ & & - & & $\begin{array}{l}\text { Transverse neck } \\
\text { incision }\end{array}$ & Winslow (1984) [15] \\
\hline 6 & 9 months & $\mathrm{F}$ & - & + & + & + & + & & & + & $3 \times 4 \times 6.5$ & & Rhee (1988) [16] \\
\hline 7 & 18 months & $\mathrm{F}$ & - & & - & + & + & & & - & $4 \times 3$ & $\begin{array}{l}\text { Transverse neck } \\
\text { incision }\end{array}$ & Billmire (1995) [17] \\
\hline 8 & 22 months & $F$ & + & & + & + & + & & & - & 4 & & Barzilai (1995) [18] \\
\hline \multirow[t]{2}{*}{9} & \multirow[t]{2}{*}{0 day } & \multirow[t]{2}{*}{ M } & & & & & & \multirow{4}{*}{$\begin{array}{l}\text { Esophageal web, } \\
\text { TEF }\end{array}$} & & + & & Neck incision & Snyder (1996) [19] \\
\hline & & & & & & & & & & & & Right thoracotomy & \\
\hline \multirow[t]{2}{*}{10} & \multirow[t]{2}{*}{2 years } & \multirow[t]{2}{*}{$\mathrm{F}$} & \multirow[t]{2}{*}{+} & & \multirow[t]{2}{*}{-} & \multirow[t]{2}{*}{$-\rightarrow+$} & \multirow[t]{2}{*}{+} & & $\begin{array}{l}24 \text { weeks: cystic } \\
\text { lesion }\end{array}$ & & $5 \times 5$ & \multirow[t]{2}{*}{$\begin{array}{l}\text { Transverse neck } \\
\text { incision }\end{array}$} & \multirow[t]{2}{*}{ McCullagh (2000) [20] } \\
\hline & & & & & & & & & $\begin{array}{l}32 \text { weeks: not } \\
\text { detected }\end{array}$ & & & & \\
\hline 11 & 0 day & $\mathrm{F}$ & + & & & + & + & Intubation (DOL2) & - & + & $\begin{array}{l}6.2 \times \\
3.4 \times 0.5\end{array}$ & & $\begin{array}{l}\text { Wootton-Gorges } \\
\text { (2002) [21] }\end{array}$ \\
\hline \multirow[t]{2}{*}{12} & \multirow[t]{2}{*}{1 year } & \multirow[t]{2}{*}{ M } & & & \multirow[t]{2}{*}{+} & & + & Bronchogenic cyst & & - & & \multirow{2}{*}{$\begin{array}{l}\text { Left thoracotomy, } \\
\text { transverse neck } \\
\text { incision }\end{array}$} & \multirow[t]{2}{*}{ Yasufuku (2003) [22] } \\
\hline & & & & & & & a & Sequestration & & & & & \\
\hline 13 & 13 months & M & + & + & & & + & & & - & $1.5 \times 2.0$ & Neck incision & Moulton (2005) [23] \\
\hline 14 & 3 years & M & - & - & - & + & + & $\begin{array}{l}\text { Drooping of the } \\
\text { eyelid }\end{array}$ & & & 5 & $\begin{array}{l}\text { Transverse neck } \\
\text { incision }\end{array}$ & Sharma (2005) [24] \\
\hline 15 & $\begin{array}{l}22 \text { weeks } \\
\mathrm{G} / \mathrm{A}\end{array}$ & M & - & - & & & + & & & & $\begin{array}{l}1 \times 0.8 \times \\
1.5\end{array}$ & $\begin{array}{l}\text { (Resection at } 6 \\
\text { month planned) }\end{array}$ & Sherer (2009) [25] \\
\hline 16 & 9.5 months & M & + & & & & + & & & & $\begin{array}{l}2.8 \times \\
2.4 \times 1.2\end{array}$ & Right thoracotomy & Nayan (2010) [26] \\
\hline 17 & 6 months & M & + & - & - & - & + & & & & $2 \times 2 \times 2$ & $\begin{array}{l}\text { Skin crease neck } \\
\text { incision }\end{array}$ & Gupta (2010) [27] \\
\hline
\end{tabular}


Table 1 A literature review of infantile cases of cervical esophageal duplication cyst (Continued)

\begin{tabular}{|c|c|c|c|c|c|c|c|c|c|c|c|c|c|}
\hline 18 & 3 months & M & + & - & + & & + & & & + & $6 \times 2$ & $\begin{array}{l}\text { Skin crease neck } \\
\text { incision }\end{array}$ & V. Kumar (2010) [28] \\
\hline 19 & 3 months & $\mathrm{F}$ & - & - & & & + & & + & - & $\begin{array}{l}2.5 \times \\
2.2 \times 4.5\end{array}$ & $\begin{array}{l}\text { Thoracoscopic } \\
\text { resection }\end{array}$ & S.Y Lee (2013) [29] \\
\hline 20 & 0 day & $\mathrm{F}$ & $-\rightarrow+$ & $-\rightarrow^{\mathrm{b}}$ & - & + & + & $\begin{array}{l}\text { Intubation } \\
\text { (DOL14) }\end{array}$ & & - & $\begin{array}{l}4 \times 2.4 \times \\
3.3\end{array}$ & $\begin{array}{l}\text { Transverse neck } \\
\text { incision }\end{array}$ & Present case \\
\hline
\end{tabular}

G/A gestational age, $F$ female, $M$ male, TEF tracheoesophageal fistula, $D O L$ days of life, US ultrasonography ${ }^{\mathrm{a}}$ By bronchogenic cyst

'Tube feeding 
included in the differential diagnosis of an infant with airway stenosis. Communication with the esophagus was present in four cases $(20 \%)$; this frequency was more than the previously reported $10 \%$ [7, 30]. Antenatal ultrasonography detected the cervical esophageal duplication cysts in two cases, underscoring the value of this prenatal test.

\section{Conclusions}

This report described a very rare case of a neonate with cervical esophageal duplication cyst that was found at birth. Airway stenosis was progressive and required airway control with tracheal intubation. Exploration at 1 month of age led to the resolution of airway stenosis.

According to 19 case reports and our own, respiratory distresses caused by external compression and deviation of the trachea commonly occur in infantile cervical esophageal duplication. We assume that cervical esophageal duplication cysts should be included in the differential diagnosis of an infant with respiratory distress and airway stenosis. Definitive diagnosis is based on histopathological findings, and surgical removal of the cyst is the treatment of choice.

\section{Consent}

Written informed consent was obtained from the patient for publication of this case report and any accompanying images. A copy of the written consent is available for review by the Editor-in-Chief of this journal.

\section{Abbreviations \\ BPFM: bronchopulmonary foregut malformations; MRI: magnetic resonance imaging.}

\section{Competing interests}

The authors declare that they have no competing interests.

\section{Authors' contributions}

SK wrote the manuscript and literature search. OS reviewed and edited manuscript. OS and YN supervised the study. SK, OS, SK, MT, NH, and HH treated and observed the patient. MF performed pathological analysis. All authors read and approved the final manuscript.

\section{Author details}

'Department of Surgery, Tokyo Women's Medical University Medical Center East, 2-1-10 Nishi Ogu, Arakawa-ku, Tokyo 116-8567, Japan. ²Department of Pediatric Surgery, Tokyo Women's Medical University, 8-1 Kawada-cho, Shinjuku-ku, Tokyo, Japan. ${ }^{3}$ Division of Neonatal Intensive Care, Tokyo Women's Medical University Medical Center East, 2-1-10 Nishi Ogu, Arakawa-ku, Tokyo 116-8567, Japan. ${ }^{4}$ Department of Diagnostic Pathology, Tokyo Women's Medical University Medical Center East, 2-1-10 Nishi Ogu, Arakawa-ku, Tokyo 116-8567, Japan.

Received: 11 January 2016 Accepted: 28 March 2016 Published online: 01 April 2016

\section{References}

1. Arbona JL, Fazzi JG, Mayoral J. Congenital esophageal cysts: case report and review of literature. Am J Gastroenterol. 1984;79(3):177-82.

2. Cohen SR, Geller KA, Birns JW, Thompson JW, Meyer BW, Lindesmith GG. Foregut cysts in infants and children. Diagnosis and management. Ann Otol Rhinol Laryngol. 1982;91:622-7.
3. Buckner CB, Walker CW, Shah HR, Fitzrandolph RL. Bronchogenic cysts. Am Fam Phys. 1989:40:167-72.

4. Van Dam J, Rice TW, Sivak Jr MV. Endoscopic ultrasonography and endoscopically guided needle aspiration for the diagnosis of upper gastrointestinal tract foregut cysts. Am J Gastroenterol. 1992;87(6):762-5

5. Gerle RD, Jaretzki 3rd A, Ashley CA, Berne AS. Congenital bronchopulmonary-foregut malformation. Pulmonary sequestration communicating with the gastrointestinal tract. N Engl J Med. 1968;278(26):1413-9.

6. Nobuhara KK, Gorski YC, La Quaglia MP, Shamberger RC. Bronchogenic cysts and esophageal duplications: common origins and treatment. J Pediatr Surg. 1997;32(10):1408-13.

7. Stringel G, Mercer S, Briggs V. Esophageal duplication cyst containing a foreign body. Can Med Assoc J. 1985;132(5):529-31.

8. Sodhi KS, Saxena AK, Rao KL, Singh M, Suri S. Esophageal duplication cyst: an unusual cause of respiratory distress in infants. Pediatr Emerg Care. 2005;21(12):854-6.

9. Hsieh YY, Hsueh S, Hsueh C, Lin JN, Luo CC, Lai JY, et al. Pathological analysis of congenital cervical cysts in children: 20 years of experience at Chang Gung Memorial Hospital. Chang Gung Med J. 2003;26(2):107-13.

10. Lund DP. Alimentary tract duplications. In: Coran AG, Caldamone A, editors. Pediatric Surgery. 7th ed. Philadelphia PA: Elsevier Mosby; 2012. p. 1155-63.

11. Cioffi U, Bonavina L, De Simone M, Santambrogio L, Pavoni G, Testori A, et al. Presentation and surgical management of bronchogenic and esophageal duplication cysts in adults. Chest. 1998;113(6):1492-6.

12. Tapia RH, White VA. Squamous cell carcinoma arising in a duplication cyst of the esophagus. Am J Gastroenterol. 1985;80(5):325-9.

13. Bishop HC, Koop CE. Surgical management of duplications of the alimentary tract. Am J Surg. 1964;107:434-42.

14. Gans SL, Lackey DA, Zuckerbraun L. Duplications of the cervical esophagus in infants and children. Surgery. 1968;63(5):849-52.

15. Winslow RE, Dykstra G, Scholten DJ, Dean RE. Duplication of the cervical esophagus. An unrecognized cause of respiratory distress in infants. Am Surg. 1984;50(9):506-8.

16. Rhee RS, Ray 3rd CG, Kravetz MH, Langer B, Harris V, Grewe GM, et al. Cervical esophageal duplication cyst: MR imaging. J Comput Assist Tomogr. 1988;12(4):693-5.

17. Billmire DF, Allen JE. Duplication of the cervical esophageal in children. J Pediatr Surg. 1995;30(10):1498-9.

18. Barzilai M, Sela L. Cervical esophageal duplication cyst: case report and review of the literature. Dig Surg. 1995;12:199-202.

19. Snyder CL, Bickler SW, Gittes GK, Ramachandran V, Ashcraft KW. Esophageal duplication cyst with esophageal web and tracheoesophageal fistula. J Pediatr Surg. 1996;31(7):968-9.

20. McCullagh M, Bhuller AS, Pierro A. Antenatal identification of a cervical oesophageal duplication. Pediatr Surg Int. 2000;16(3):204-5.

21. Wotton-Gorges SL, Eckel GM, Poulos ND, Kappler S, Milstein JM. Duplication of the cervical esophagus: a case report and review of literature. Pediatr Radiol. 2002;32(7):533-5.

22. Yasufuku M, Hatakeyama T, Maeda K, Yamamoto T, I wai Y. Bronchopulmonary foregut malformation: a large bronchogenic cyst communicating with an esophageal duplication cyst. J Pediatr Surg. 2003;38(2):e2.

23. Moulton MS, Moir C, Matsumoto J, Thompson DM. Esophageal duplication cyst: a rare cause of biphasic stridor and feeding difficulty. Int J Pediatr Otorhinolaryngol. 2005;69(8):1129-33.

24. Sharma KK, Ranka P, Meratiya S. Isolated cervical esophageal duplication: a rarity. J Pediatr Surg. 2005;40(3):591-2

25. Sherer DM, Timor-Tritsch IE, Dalloul M, Zinn H, Sokolovski M, Kheyman M, et al. Prenatal sonographic findings of an isolated cervical esophageal duplication cyst. J Ultrasound Med. 2009;28(3):405-7.

26. Nayan S, Nguyen LH, Nguyen VH, Daniel SJ, Emil S. Cervical esophageal duplication cyst: case report and review of the literature. J Pediatr Surg. 2010;45(9):e1-5.

27. Gupta B, Meher R, Raj A, Agarwal S. Duplication cyst of oesophagus: a case report. J Paediatr Child Health. 2010;46(3):134-5.

28. Kumar V, Singh AP, Meher R, Raj A, Aggarwal SK. Congenital esophageal duplication cyst: a rare cause of infantile stridor and a diagnostic challenge. Int J Pediatr Otorhinolaryngol Extra. 2010;5:162-4. 
29. Lee SY, Kim HY, Kim SH, Jung SE, Park KW. Thoracoscopic resection of a cervical esophageal duplication cyst in a 3-month-old infant: a case report. Pediatr Surg. 2013;48(4):873-5.

30. Akiyama S, Sakamoto J, Suyama M, Imaizumi M, Ichihashi H, Kondo T.

Esophageal cyst, a case report and a review of the literature. Jpn I Surg. 1980;10(4):338-42

\section{Submit your manuscript to a SpringerOpen ${ }^{\circ}$} journal and benefit from:

- Convenient online submission

- Rigorous peer review

- Immediate publication on acceptance

- Open access: articles freely available online

- High visibility within the field

- Retaining the copyright to your article

Submit your next manuscript at $>$ springeropen.com 